\title{
Private Challenges to Prosecutorial Inaction: A Model Declaratory Judgment Statute
}

\author{
Stuart P. Green
}

As litigants in American criminal proceedings, private persons generally are relegated to the role of defendant. Prosecutors acting on behalf of the government carry out the plaintiff's role, exercising exclusive control over the initiation and execution of criminal prosecutions. As a consequence, while private persons who are defendants in criminal proceedings are able to challenge prosecutors' decisions to prosecute and to have such decisions subjected to judicial review, ${ }^{1}$ in most jurisdictions such persons may not challenge prosecutors' decisions not to prosecute. ${ }^{2}$ However, private persons need not categorically be denied standing in such cases. Given a statute upon which to base a claim, private persons can successfully challenge the decisions of prosecutors not to prosecute. ${ }^{3}$ Although federal law lacks such a statute, at least nine states have, or recently had, statutory schemes that potentially enable private persons to challenge prosecutorial inaction. ${ }^{4}$

1. See, e.g., Yick Wo v. Hopkins, 118 U.S. 356, 373 (1886) (reversing conviction of Chinese laundry owners for operating laundry contrary to city ordinance because ordinance, though "fair on its face," was administered in violation of the equal protection clause of the Fourteenth Amendment).

2. See Linda R.S. v. Richard D., 410 U.S. 614,619 (1973) ("a citizen lacks standing to contest the policies of the prosecuting authority when he himself is neither prosecuted nor threatened with prosecution"). The plaintiff in the case was the mother of an illegitimate child who sued to enjoin the "discriminatory application" of a Texas statute which had been construed to subject to prosecution only the parents of legitimate children. Holding that the plaintiff had no standing to challenge the statute, the Court said that the only proper party to challenge the law would have been the parent of a legitimate child who was himself subject to prosecution. Id. at $619 \mathrm{n} .5$.

3. Cf. id at 617 n.3 (refusing to permit a private individual to force local district attorney to prosecute "[i]n the absence of a statute expressly conferring standing").

4. See Ala. Code § 12-17-186 (1986); Colo. Rev. Stat. \& 16-5-209 (1986); Mich. Comp. Laws $§ 767.41$ (1982); MinN. STAT. $§ 388.12$ (1968 \& Supp. 1986); NEB. Rev. STAT. § 29-1606 (1979); N.D. Cent. Code $\$ 11-16-06$ (1985); 16 Pa. Cons. Stat. ANN. § 1409 (Purdon 1956); Wis. Stat. ANN. $\$ 968.02(3)$ (West 1985) (ruled unconstitutional in State ex rel. Unnamed Petitioners v. Connors, 136 Wis. 2d 118, 401 N.W.2d 782 (1987)); Wyo. Srat. § 7-6-110 (1977) (repealed 1985) (ruled unconstitutional in In re Padget, 678 P.2d 870 (Wyo. 1984)); see also MoDEL. Code Of Pre-Arraignment Procedure $\$ 6.02$ (Proposed Official Draft 1966) (private challenge statute provides a "check upon the district attorney who fails to authorize the issuance of a complaint"), used as a model for the Wisconsin statute. There is very little reported case law involving any of these statutes; indications are that such statutes are used rarely and that, when use has been contemplated, judges usually have been able to dissuade private complainants from pursuing their claims. Telephone interview with E. Michael McCann, District Attorney of Milwaukee County (Oct. 14, 1986).

Not all of these "private challenge" statutes expressly confer standing on private persons to chal- 
This Note begins with an outline of the policy considerations favoring standing for private persons to challenge the decisions of prosecutors not to prosecute..$^{5}$ It then describes several types of statutes providing for "private challenges" and examines the constitutional problems with each. Adopting a methodology based on principles developed in the body of federal constitutional law, ${ }^{8}$ the Note argues that, while private prosecution and court-ordered prosecution are constitutionally untenable, Congress and state legislatures may, consistent with the Constitution, provide for citizen standing to challenge prosecutorial inaction. Finally, the Note proposes a model statute that would allow a private person who is the victim of an alleged criminal act to make such a challenge. The statute would authorize a court, upon an appropriate finding, to issue a declaratory judgment that a prosecutor has abused his discretion not to prosecute. While this judgment would not require that a prosecution be commenced, it could be expected to create public pressure on the prosecutor, giving the plaintiff political leverage that he might not otherwise have. In addition, the statutory procedure would allow for a public airing of grievances and serve as a device for "signalling" executive abuse of discretion.

\section{Policy Reasons For Allowing Private Challenges to Prosecutorial Inaction}

Federal and state statutes typically require that "all prosecutions" be conducted by government officials. ${ }^{7}$ This grant of authority invariably has been interpreted to mean that only government prosecutors have the authority to prosecute, rather than that the government must prosecute every

lenge prosecutorial inaction. Several of the statutes provide simply for some form of judicial review. However, those that have produced judicial commentary have been construed as giving standing to private persons. See cases cited infra notes 33 and 110 . None has been used by a court to review prosecutorial inaction sua sponte.

5. The Note does not offer an extended argument in favor of legal recognition of the interests of private individuals in criminal prosecutions. Instead, the focus of Section $I$ is on the inadequacies of current forms of such recognition.

6. This federally based methodology reflects three significant characteristics of state constitutional jurisprudence. First, the structure of many state constitutions parallels the structure of the federal Constitution. See infra notes 70, 71, 74 and 84 . Second, several states have made changes recently in the structure of their constitutions in order to reflect more explicitly the federal model of separation of powers. See, e.g., ConN. ConsT. amend. XXIII (establishing, for the first time in the state's history, a criminal justice system located expressly within the executive branch). This amendment marked a significant change from the old procedure, under which state's attorneys were appointed exclusively by judges, and seemed to reflect a conscious concern with maintaining the independence of the prosecutor's office from the judicial branch. See Transcript of Connecticut Legislative Hearings on Proposed Amendment, March 5, 1984 (statement of Austin McGuigan, Chief State's Attorney, opposing the amendment). Finally, even where such structural parallels do not exist, state courts have exhibited a tendency to emulate federal separation of powers doctrine in determining the allocation of powers under their own state constitutions, see cases cited infra notes 66 and 70, perhaps because separation of powers law is most developed at the federal level.

7. See, e.g., 28 U.S.C. $§ 547$ (1982) ("Except as otherwise provided by law, each United States attorney, within his district, shall-(1) prosecute for all offenses against the United States . . .."). 
offense. $^{8}$ Thus, a prosecutor's discretion whether to initiate a criminal proceeding ${ }^{\theta}$ may be thought of as the gap between the authority to prosecute a case and the actual prosecution of that case. ${ }^{10}$

Allowing prosecutors this area of discretion within which to formulate prosecutorial policy undoubtedly serves valuable purposes in the criminal justice system, ${ }^{11}$ but such discretion also holds the potential for abuse. ${ }^{12} \mathrm{~A}$ number of systemic reforms have been proposed that, by rationalizing the process of deciding whether to prosecute, would retain many of the benefits of prosecutorial discretion while minimizing its dangers. ${ }^{13}$ These proposals, if adopted, might well help to minimize abuse of prosecutorial discretion in the aggregate. Nevertheless, the criminal justice system still would be unable to address the individual concerns ${ }^{14}$ of the party most

8. See, e.g., United States v. Hall, 559 F.2d 1160, 1163 (9th Cir.) (interpreting § 547), cert. denied, 435 U.S. 942 (1977). For further discussion of the basis and limits of the power to, and not to, prosecute, see infra notes 68-82 and accompanying text.

9. The prosecutor's discretion over whether to initiate criminal proceedings is only one aspect of his discretion, which also encompasses the decision of what to charge, whether to accept a plea to a lesser charge, and whether to file a motion to dismiss a charge already brought. See generally Abrams, Prosecutorial Discretion, in 3 EnCyClopedia of CRIME AND Justice 1272 (S. Kadish ed. 1983).

10. Cf. R. Dworkin, The Model of Rules $I$, in TAking Rights SERIousLy 14, 31 (1977) ("Discretion [in the law generally], like the hole in a doughnut, does not exist except as an area left open by a surrounding belt of restriction."). Two distinct senses of discretion emerge from Dworkin's discussion: (1) discretion where there are no clear standards by which an official must make decisions; and (2) discretion where an official has final authority to make decisions that cannot be reviewed or reversed by any other official. See id. at 31-32. For more on this distinction, see infra note 15 and accompanying text.

11. Prosecutorial discretion facilitates the efficient allocation of limited prosecutorial, judicial, and penal resources. It also helps to individualize and humanize the criminal law, allowing the system to deal flexibly with laws that overlap, laws that have become antiquated, laws that are necessarily broad, and laws that are intended primarily to express social disapproval for particular behavior rather than to be consistently enforced. See Breitel, Controls in Criminal Law Enforcement, 27 U. ChI. L. Rev. 427, 429 (1960); Cox, Prosecutorial Discretion: An Overview, 13 AM. CRIM. L. Rev. 383, 385-91 (1976).

12. See Vorenberg, Decent Restraint of Prosecutorial Power, 94 Harv. L. Rev. 1521, 1555 (1981) ("Giving prosecutors the power to invoke or deny punishment at their discretion raises the prospect that society's most fundamental sanctions will be imposed arbitrarily and capriciously and that the least favored members of the community-racial and ethnic minorities, social outcasts, the poor-will be treated most harshly."); see also $\mathbf{K}$. Davis, Discretionary Justice: A Preliminary INQUIRY 12 (1969) ("A startlingly high proportion of all official discretionary action pertaining to administration of justice is illegal or of doubtful legality.").

13. Two reforms in particular are worthy of note: (1) implementing specific administrative guidelines for the exercise of discretion, see, e.g., Abrams, Internal Policy: Guiding the Exercise of Prosecutorial Discretion, 19 UCLA L. Rev. 1 (1971) (urging use of internal policy guides to strike balance between consistent decisionmaking and need for flexibility); Bubany \& Skillern, Taming the Dragon: An Administrative Law for Prosecutorial Decision Making, 13 AM. CRIM. L. Rev, 473 (1976); and (2) requiring prosecutors to produce written reasons for their decisions not to prosecute, see, e.g., Mich. Comp. Laws $\S 767.41$ (1982); Neb. Rev. Stat. $\S 29-1606$ (1979); see also K. DAviS, supra note 12, at 203-05 (raising possibility of requiring written reasons, but recognizing attendant problems); Cardenas, The Crime Victim in the Prosecutorial Process, 9 Harv. J.L. \& PuB. PoL'y 357, 393 (1986) (proposing rule that prosecutor must notify crime victim and give written reasons for not prosecuting).

14. Obviously, victims of crimes suffer specific wrongs-death, physical and emotional harm, loss of property - that constitute real and lasting injuries, and those injuries are of greater concern to these victims than to the general population. Cf. Hall, The Role of the Victim in the Prosecution and Disposition of a Criminal Case, 28 VAND. L. Rev. 931, 948 (1975) ("IA]damant victims are observed most frequently in cases involving serious felonies. ... The prevailing prosecutorial view is that the 
likely to be dissatisfied with a prosecutor's decision not to prosecute-namely, the victim of the crime at issue. ${ }^{15}$

The question then arises whether the state should give legal recognition to the interests of individual victims in the initiation of criminal prosecutions. In recent years, the dominant view has been that it should not. Two justifications are usually offered: first, that the criminal law is inherently a matter of public law, to be dealt with between the state and the defendant; ${ }^{16}$ and second, that any interest individuals do have in dealing with individual criminal defendants may be satisfied more appropriately through civil legal action. ${ }^{17}$ However, neither justification seems warranted. Serious doubt has been raised both by writers within the victims' rights movement, who have advocated a larger role for victims in criminal proceedings, ${ }^{18}$ and by those who, in a much more general context, have questioned the very distinction between the "public" and "private" in law. ${ }^{18}$ In addition, many criminal defendants are judgment proof, and even in cases where a defendant has a sufficiently "deep pocket" to give a victim an economic incentive to file suit, a victim still cannot achieve spe-

victim who most vigorously seeks full enforcement of the criminal law is the survivor of the deceased in a homicide case.").

15. Both the administrative guidelines approach and the written reasons approach would address abuses of discretion in the first sense described supra note 10 (i.e., discretion where there are no clear standards by which an official must make decisions), but not in the second sense (i.e., discretion where an official has final authority to make decisions that cannot be reviewed or reversed by any other official).

16. See, e.g., Heckler v. Chaney, 470 U.S. 821, 847 (1985) (Marshall, J., concurring) ("Criminal prosecutorial decisions vindicate only intangible interests, common to society as a whole, in the enforcement of the criminal law. The conduct at issue has already occurred; all that remains is society's general interest in assuring that the guilty are punished."); $c f$. Booth v. Maryland, 107 S. Ct. 2529 (1987) (introduction of victim impact statement at sentencing phase of capital murder trial violates Eighth Amendment).

17. See, e.g., In re Piscanio, 235 Pa. Super. 490, 496, 344 A.2d 658, 662 (1975) ("If a private [party] feels individually harmed [by criminal activity] his remedy is a civil suit for damages.").

18. See Goldstein, The Victim and Prosecutorial Discretion: The Federal Victim and Witness Protection Act of 1982, LAw \& CONTEMP. ProBS., Autumn 1984, at 225, 226 (victims' movement advocates measures-including social services for victims who serve as witnesses, restitution or compensation, and protection from intimidation and retaliation-to involve victims more fully in the criminal justice system).

Most theorists and legislators within, or sympathetic to, the victims' rights movement have advocated victim participation only after criminal prosecution has begun. See, e.g., Victim and Witness Protection Act of 1982, Pub. L. No. 97-291, 96 Stat. 1248 (codified in scattered sections of 18 U.S.C.); President's Task Force on Victims of Crime, Final Report (1982); Goldstein, Defining the Role of the Victim in Criminal Prosecution, 52 Miss. L. REv. 515 (1982); Moss, New Tack for Victims' Rights, A.B.A. J., Mar. 1988, at 32 (describing "second generation" of victims" rights legislation-state constitutional amendments that, for example, give victims right to be present, and to be heard, at critical stages of criminal justice process, to extent that such right does not interfere with rights of accused). However, limiting victims' involvement in this manner leaves victims whose assailants are not prosecuted without redress.

19. See, e.g., Cane, Public Law and Private Law: A Study of the Analysis and Use of a Legal Concept, in OXford Essays IN JuRISPRudence 61 (J. Eekelaar \& J. Bell eds. 1987) ("since activities are not by their nature either public or private, the distinction is irrelevant to the regulation and control of human activity"); see also Kennedy, The Stages of the Decline of the Public/Private Distinction, 130 U. PA. L. REv. 1349 (1982). 


\section{cific deterrence ${ }^{20}$ and incapacitation ${ }^{21}$ of his assailant without criminal sanctions. ${ }^{22}$ \\ Thus, in most jurisdictions an individual seeking to compel a criminal prosecution has only three alternatives: using political means, ${ }^{23}$ communi- cating with a grand jury, ${ }^{24}$ and bringing an action for mandamus. ${ }^{25}$ None}

20. See W. LaFave \& A. Scott, Criminal. Law 23 (2d ed. 1986) (under specific, or particular, deterrence theory punishment is justified by the effect it has on the potential future criminal activity of the punished offender).

21. Under the theory of incapacitation, or removal of the offender from society, punishment is justified by society's desire to protect itself from a person deemed dangerous because of past criminal conduct. Id. at 23-24; $c f$. Inmates of Attica Correctional Facility v. Rockefeller, 477 F.2d 375, 378 (2d Cir. 1973) ("Where a successful prosecution ... would serve to deter the accused from harming the complainant rather than merely supply a penal inducement to perform a duty to provide assistance, the complainant does show a more direct nexus between his personal interest in protection from harm and the prosecution." (distinguishing Linda R.S. v. Richard D., 410 U.S. 614 (1973)).

22. These interests are particularly strong for victims of domestic violence, extortion, blackmail, and vandalism-crimes in which the same victims are repeatedly victimized by the same assailants. For a discussion of the methodological difficulties faced by statistical studies of such crimes, see BuReau of Justice Statistics, U.S. Dep'T of Justice, Series Crimes: Report of a Field Test (1987).

Moreover, a victim who feels that the criminal justice system is entirely unresponsive to his needs might in some extreme cases resort to "vigilante justice." Even worse, a widespread perception that the system is unresponsive might lead to public sentiment that such acts are justified. $C f$. Carter, When Victims Happen to Be Black, 97 YALE L.J. 420, 424 (1988) ("The tragedy of the [Bernhard] Goetz case is that a public barely aware of the facts was rooting for him to get away with it."). A legally sanctioned recognition of victims' interest in the initiation of criminal proceedings could help deter such antisocial behavior.

23. See, e.g., In re Padget, 678 P.2d 870, 873 (Wyo. 1984) (if private individuals "are unsatisfied [with a prosecutor's inaction], they are free to express their feelings at the polls"). In 45 states the local district attorney is directly elected, see OfFice of Legislative ResEARCH, ConN. GEN. ASSEMbly, Authority of Attorney Generals in Other States to Prosecute Crimes 4-16 (1982), and some authorities indicate that local, elected district attorneys are more likely to abuse their discretion through incompetence than are their federal, appointed counterparts, see Comment, Private Prosecution: A Remedy for District Attorneys' Unwarranted Inaction, 65 Y ALE. L.J. 209, 210 n.8 (1955) ("The [local] prosecutor's pay is low, and often only inexperienced and incompetent [people] can be attracted."). This suggests an important irony: the more representative the basis for a prosecutor's authority, the more urgent the need for effective checks on his discretion.

Moreover, only in rare cases will victims have the resources necessary to have a prosecutor removed and a new one elected in his place. In essence, the political remedy approach trivializes the fundamental role of the courts as a forum for those without viable political influence. Cf. J. MASHAw \& $R$. Merrill, Administrative Law: The American Public Law System 269 (2d ed. 1985) ("The central value of judicial review may be its residual guarantee of justice in individual cases. From this perspective judicial review protects the citizen from the extremes of bureaucratic tunnel-vision or incompetence....").

24. Since grand jury proceedings are held in secret, virtually no jurisdiction allows private complainants to make a case in person, see Annotation, Individual's Right to Present Complaint or Evidence of Criminal Offense to Grand Jury, 24 A.L.R. 4TH 316 (1983), and only a handful of states allow complainants to communicate with a grand jury in writing, see id. Indeed, 18 U.S.C. $\$ 1504$ (1985) makes it a crime for a private party to attempt to communicate with a federal grand (or petit) jury. But $c f$. Y. Kamisar, W. LaFave \& J. Israel, Modern Criminal Procedure: Cases, ComMENTS, QUESTIONS 720 n.c (5th ed. 1980) (suggesting that right to transmit written communications directly to grand jury "arguably" is guaranteed by First Amendment). Given the prosecutor's traditionally powerful influence over the grand jury, allowing victims to communicate with these juries in writing is generally ineffective.

25. Persuading a judge to issue a writ of mandamus generally is difficult and a writ ordering a prosecutor to prosecute, extraordinarily so. See Note, The Use of Mandamus to Control Prosecutorial Discretion, 13 AM. CRIM. L. REv. 563 (1976). In order to avoid using mandamus to compel prosecution, courts usually will rely on at least one of three justifications. First, courts will state that another remedy exists. See, e.g., Walsh v. LaGuardia, 269 N.Y. 437, 440, 199 N.E. 652, 653 (1936) (admin- 
of these ad hoc alternatives, however, has proven very effective. ${ }^{26} \mathrm{~A}$ statute that allows private individuals to challenge the decisions of prosecutors not to prosecute is a more direct, effective, and systematic means to answer the claims of individuals dissatisfied with a prosecutor's inaction. ${ }^{27}$

\section{Constitutional Defects in Existing Private Ghallenge Statutes}

A number of states have enacted statutes that potentially allow victims to challenge the decisions of prosecutors not to prosecute. ${ }^{28}$ These statutes may be divided into two basic types, each of which raises its own set of concerns. First, "private prosecution" statutes, which allow private persons to conduct their own prosecutions, ${ }^{29}$ raise concerns primarily about the rights of defendants ${ }^{30}$ and, in addition, about the appropriateness of delegating an exclusively executive function to private parties. ${ }^{31}$ Second, statutes that allow a court to order a prosecutor to proceed with a previ-

istrative procedures available for plaintiff to object to plan for municipal bus routes). Second, courts will say that mandamus is available to compel only "ministerial" tasks, where official duty is clear, and not "discretionary" acts, such as prosecution. See Note, Reviewability of Prosecutorial Discretion: Failure to Prosecute, 75 Colum. L. REv. 130, 134 \& n.27 (1975) [hereinafter Note, Failure to Prosecute]. Third, courts will find that plaintiffs lack standing. See, e.g., Nader v. Saxbe, 497 F.2d 676, 680 (D.C. Cir. 1974) (voter had no standing to compel by mandamus prosecution of violations of Federal Corrupt Practices Act); see also Brill, The Citizen's Relief Against Inactive Federal Officials: Case Studies in Mandamus, Actions "in the Nature of Mandamus," and Mandatory Injunctions, 16 Akron L. REV. 339, 394 (1983) (suggesting that actions to compel criminal prosecutions "present a far more significant problem in terms of standing" than suits to compel government civil action). For a rare instance of a case in which a court found mandamus an "appropriate" remedy for nonprosecution, see NAACP v. Levi, 418 F. Supp. 1109, 1117 (D.D.C. 1976), discussed infra note 106.

26. See supra notes 23-25; see also Comment, supra note 23, at 213-15 (discussing inadequacy of alternatives to private prosecution).

27. Before adopting such a statute, a legislature would have to determine both the seriousness of prosecutorial abuse and the extent of public dissatisfaction with prosecutorial inaction in its jurisdiction. This Note does not explore that threshold policy discussion but rather suggests a procedure for private challenge to prosecutorial inaction that is constitutionally sound.

28. For a listing, see supra note 4.

29. See 16 PA. Cons. STAT. ANN. $\S 1409$ (Purdon 1956) ("[court] may direct any private counsel employed by [complainant] to conduct the entire [criminal] proceeding"); see also Tonkin v. Michael, 349 F. Supp. 78 (D.V.I. 1972) (court allowed complainants to prosecute with private attorneys when public prosecutor refused to file criminal charges); People v. Van Sickle, 13 N.Y.2d 61, 241 N.Y.S.2d 34, 192 N.E.2d 9 (1963) (criminal conviction need not be reversed solely because complaining lay witness was allowed to conduct prosecution); Comment, supra note 23, at 215 (advocating scheme whereby "court would have the power to appoint a privately hired attorney to act as the public prosecutor for a single action").

30. See infra Section II-A.

31. Challenges to statutes that allow private individuals to assume assertedly exclusive executive functions have been made recently in the administrative law context, but with little success so far. See, e.g., Chesapeake Bay Found. v. Bethlehem Steel Corp., 652 F. Supp. 620, 623-25 (D. Md. 1987) (citizen suit provision of Clean Water Act does not violate separation of powers). In Chesapeake Bay, the court considered explicitly the analogy to criminal prosecution and found that "the doctrine of prosecutorial discretion cautions [only] courts against interfering with the executive decisions concerning criminal prosecution." Id. at 624. Given the early history of private prosecution in this country, see infra note 39 , there may be good precedent for this conclusion. Issues pertaining to the delegation of the prosecution function are raised in the discussion of separation of powers objections to courtordered prosecution statutes, see infra Section II-B. 
ously declined prosecution ${ }^{32}$ or to appoint a special prosecutor to take control of a case ${ }^{33}$ raise objections primarily concerning separation of powers, ${ }^{34}$ and, ultimately, about due process as well. ${ }^{35}$ Statutes providing for some combination of these procedures for redressing prosecutorial inaction $^{36}$ may contain all of the mentioned flaws.

\section{A. Private Control of Prosecutions}

Historically, private individuals often were able to bring prosecutions themselves. ${ }^{37}$ Private prosecution still is practiced in England, ${ }^{38}$ and in

32. See Mich. CoMP. LAws $\S 767.41$ (1982) (if court is not "satisfied with the [prosecutor's] statement [of reasons for not prosecuting], the prosecuting attorney shall be directed by the court to file the proper information and bring the case to trial"), construed in Genesee County Prosecutor v. Genesee Circuit Judge, 391 Mich. 115, 121, 215 N.W.2d 145, 147 (1974) (judge "may not properly substitute his judgment for that of the . . prosecuting attorney. He may reverse or revise [the prosecutor's] decision[] only if it appears on the record that [he] ha[s] abused the power confided to [him]." (footnote omitted)), appeal after remand sub nom. People v. Hoskins, 403 Mich. 95, 267 N.W.2d 417 (1978); NEB. REv. STAT. \$ 29-1606 (1979) (if court is not satisfied with prosecutor's stated reasons for refusing to prosecute, "the county attorney shall be directed by the court to file the proper information and bring the case to trial"); WYo. STAT. \$ 7-6-110 (1977) (repealed 1985) (authorizing trial judge to monitor reluctant prosecutor's "compliance with the order" to prosecute) (ruled unconstitutional in In re Padget, 678 P.2d 870 (Wyo. 1984), discussed infra note 60); see also Cardenas, supra note 13, at 393 (proposing scheme under which, "[i]f the court should find that sufficient grounds for the public prosecution exists [sic], it could sanction the prosecution and the corresponding [civil] action"); Note, Discretion to Prosecute Federal Civil Rights Crimes, 74 YaLE L.J. 1297, 1309 (1965) (proposing procedure by which private citizens could compel, by judicial mandamus, federal authorities to bring prosecutions of civil rights crimes).

33. See ALA. CoDE $\S 12-17-186$ (1986) ("when the district attorney refuses to act, [the court] may appoint competent [public] attorney to act in such district attorney's place"); MinN. STAT. $\S 388.12$ (1968 \& Supp. 1986) (allowing a judge to appoint an "attorney" to act "as or in the place of" the county attorney), construed in State ex rel. Wild v. Otis, 257 N.W.2d 361, 365 (Minn.), cert. denied, 434 U.S. 1003 (1977) ("Arguably, a private citizen could petition the district court for action pursuant to this statute and the court could appoint a special prosecutor if it decided that this was necessary." (citations omitted)); N.D. CENT. CODE § 11-16-06 (1985) (if court finds that "state's attorney has refused or neglected to perform" it may appoint a different "attorney to take charge of" case), construed in Hennebry v. Hoy, 343 N.W.2d 87, 92 n.3 (N.D. 1983) (statute limits prosecutorial discretion in a "practical sense"); see also Colo. Rev. STAT. \$ 16-5-209 (1986) ("If after a hearing the judge finds that the refusal of the prosecuting attorney to prosecute was arbitrary or capricious and without reasonable excuse, he may order the prosecuting attorney to file an information and prosecute the case or may appoint a special prosecutor to do so." (emphasis added)). The Colorado statute is discussed in Tooley v. District Court, 190 Colo. 468, 549 P.2d 772 (1976) (implying that statute is constitutional) and in Dohaish v. Tooley, 670 F.2d 934, 937-38 (10th Cir. 1982) (while plaintiff who alleged that district attorney had discriminated against him by failing to prosecute alleged murderer of plaintiff's son had no standing to compel prosecution under 42 U.S.C. $\$ 1983$, plaintiff could bring such an action under Colorado law).

34. See infra Section II-B.

35. See infra note 63.

36. See Wis. Stat. ANN. $\S 968.02(3)$ (West 1985) (judge may, upon finding of probable cause, permit private person to file complaint when district attorney refuses to initiate proceedings). In practice, the Wisconsin statute, recently declared unconstitutional, see infra note 110 , left the choice of subsequent procedures within the discretion of the trial judge. Telephone interview with James Walrath, attorney in Milwaukee (Sept. 25, 1986).

37. See Goldstein, Prosecution: History of the Public Prosecutor, in 3 ENCycLopedia of Crime AND Justice 1286 (S. Kadish ed. 1983); Langbein, The Origins of Public Prosecution at Common Law, 17 AM. J. Legal Hist. 313 (1973).

38. See generally Cardenas, supra note 13 ("[English] [p]olice prosecutions are, at least in legal theory, private prosecutions. English common law maintains that police officers [who generally initiate and conduct criminal proceedings] are not distinct from the general body of citizens."). The recent 
this country privately initiated and conducted prosecution was the principal form of prosecution prior to the institution of government prosecutorial offices. ${ }^{39}$ In the United States today, however, only a handful of jurisdictions still allow private individuals to initiate and "privately prosecute" a criminal case. ${ }^{40}$

The primary problem with these statutes is that they compromise a criminal defendant's due process right to be prosecuted by a disinterested prosecutor. Several states have come to this conclusion only in recent years, ${ }^{11}$ and at least one state has maintained the position that the permissibility of private prosecution ought to turn on a case-by-case determination of whether a defendant's rights actually have been compromised. ${ }^{42}$ Nevertheless, the Supreme Court, acting in its supervisory capacity over the Federal Rules of Criminal Procedure, recently established a "categorical rule" against the appointment of an interested prosecutor. ${ }^{43}$

In Young v. United States ex rel. Vuitton et Fils, the Court considered

Prosecution of Offences Act, 1985, s.1 et seq., explicitly retains a citizen's right to private prosecution. But of. Samuels, Non-Crown Prosecutions: Prosecutions by Non-Police Agencies and by Private Individuals, 1986 CRIM. L. REv. 33, 43 (noting that new Crown Prosecution Service will assume responsibility for increasing number of prosecutions).

39. American jurists, under the influence of Continental theory, see, e.g., C. BeCCARIA, ON Crimes and Pinishment (D. Young ed. 1986) (1st ed. 1764), began developing a system of public prosecution around the time of the American Revolution. The most significant step in this direction was the enactment of the Judiciary Act of 1789, ch. 20, 1 Stat. 73, which provided, inter alia, for presidential appointment of federal prosecutors in each district. The Attorney General had no formal control over these prosecutors, however, until 1861, and the Department of Justice was not officially established until 1870. Pomerantz, Prosecution: United States Attorney, in 3 ENCyclopedia of CRIME AND Justice 1291 (S. Kadish ed. 1983). Development of public prosecutorial offices in the states lagged even further behind. See Steinberg, From Private Prosecution to Plea Bargaining: Criminal Prosecution, the District Attorney, and American Legal History, 30 CRIME \& DeliNQUENCY 568 (1984).

40. See supra note 29.

41. See, e.g., State v. Harrington, 534 S.W.2d 44, 48-49 (Mo. 1976) (overturning privately prosecuted murder conviction; private prosecution called "inherently and fundamentally unfair" despite years of use in state); People v. Municipal Court, 27 Cal. App. 3d 193, 206, 103 Cal. Rptr. 645, 654-55 (1972) (Trial court's procedure allowing private complainant to file complaint and have her attorney act as prosecutor ruled unconstitutional: "Due process of law requires that . . the institution of any criminal proceeding be authorized and approved by the district attorney."); see also Note, The Outmoded Concept of Private Prosecution, 25 AM. U.L. Rev. 754 (1976) (arguing that violations of due process are inherent in private management of criminal prosecution); Note, Private Prosecution-The Entrenched Anomaly, 50 N.C.L. REv. 1171 (1972) (similar).

42. See People v. Vial, 132 Misc. 2d 5, 14, 502 N.Y.S.2d 930, 936 (N.Y. Crim. Ct. 1986) (court expressing confidence that "a trial judge hearing this matter will be sensitive to the delicate balance necessary to afford all parties the fundamental fairness and substantial justice that due process requires" (citations omitted)); People ex rel. Luceno v. Guozzo, 97 Misc. 2d 871, 876, 412 N.Y.S.2d 748,751 (N.Y. Sup. Ct. (1978) ("The court is in a better position to control the . . case by the exercise of discretion than in fashioning an absolute rule that in all cases or in no cases can such private attorney proceed.").

Even in New York, however, the rule has been that the district attorney must conduct criminal proceedings in "serious" cases (i.e., where the maximum penalty exceeds six months), the theory being that in more serious cases the "People [of the state] are entitled to be represented by counsel they have selected, the District Attorney." See People v. Vlasto, 78 Misc. 2d 419, 422, 355 N.Y.S.2d 983, 986 (N.Y. Crim. Ct. 1974).

43. Young v. United States ex rel. Vuitton et Fils, 107 S. Ct. 2124, 2141 (1987). Adherence to this rule, the Court said, requires "no subtle calculations of judgment." Id. 
the propriety of interested private counsel acting as prosecutors in federal criminal contempt proceedings arising out of alleged violations of an injunction in an underlying civil suit. ${ }^{4}$ While stopping short of declaring that the due process clause absolutely guarantees a criminal defendant the right to an impartial government prosecutor, ${ }^{45}$ the Court found appointment of Vuitton's counsel in these circumstances to be "improper." 48 The Vuitton holding does not bind Congress or state legislatures to adopt the same categorical rule. Yet the Court's recognition of the significant dangers to defendants' rights resulting from private prosecution ${ }^{47}$ cautions against retention of such procedures.

\section{B. Judicial Supervision of the Prosecutor}

In light of these due process concerns, statutes allowing courts to order the prosecutor to prosecute ${ }^{48}$ or to appoint a special prosecutor ${ }^{48}$ upon a finding of abuse of discretion appear an attractive alternative. Yet such procedures raise another constitutional problem: Prosecution typically is an executive branch function, ${ }^{\text {,0 }}$ and allowing a judge the power of appointment, removal, or supervision over prosecutors threatens to diminish exclusively executive powers and to augment the constitutionally limited role of judicial authority.

Not every judicial appointment or removal of officials who exercise executive functions is prohibited. Under the federal constitution, the appointments clause ${ }^{51}$ provides expressly that judges may appoint "inferior" executive officers when Congress so provides. ${ }^{52}$ In addition, an analogous

44. Plaintiff Vuitton's private attorney was appointed by the court as a "special prosecutor" pursuant to Federal Rules of Criminal Procedure 42(b) both to conduct an investigation (which included court-sanctioned undercover work) and to prosecute defendants for their violation of an injunction prohibiting infringement of plaintiff's trademark. Defendants ultimately received sentences ranging from six months to five years. Id. at 2128 .

45. Justice Blackmun, however, in his brief concurrence, wrote that he would go even further than the Court's holding: "[T]he practice-federal or state-of appointing an interested party's counsel to prosecute for criminal contempt is a violation of due process." Id. at 2141 (Blackmun, J., concurring); see also Note, Private Prosecutors in Criminal Contempt Actions Under Rule 42(b) of the Federal Rules of Criminal Procedure, 54 Fordham L. Rev. 1141 (1986) (arguing same).

46. $107 \mathrm{~S}$. Ct. at 2141.

47. The Court in Vuitton recognized that "[p]rosecutors "have available a terrible array of coercive methods to obtain information,' such as 'police investigation and interrogation, warrants, informers and agents whose activities are immunized, authorized wiretapping, civil investigatory demands, [and] enhanced subpoena power." $107 \mathrm{~S}$. Ct. at 2139 (quoting C. Wolfram, Modern LeGal. ETHICs 460 (1986)).

48. See supra note 32 .

49. See supra note 33 .

50. For a discussion of the specific constitutional locus of the prosecutorial function, see infra notes 68-82 and accompanying text.

51. U.S. Const. art. II, $\$ 2$, cl. 2 ("Congress may, by law, vest the appointment of such inferior Officers, as they think proper . . . in the Courts of Law . ...").

52. See Rice v. Ames, 180 U.S. 371, 378 (1901) (extradition commissioners may properly be appointed by courts); Ex parte Siebold, 100 U.S. 371,398 (1880) (election officers may properly be appointed by courts). 
body of removability doctrine ${ }^{53}$ provides that Congress may restrict the executive's power to remove such inferior officers. ${ }^{54}$ However, where an officer exercises core executive functions, Congress may not, with two narrow exceptions, delegate power to appoint that officer to nonexecutive officials ${ }^{\mathrm{bS}}$ or restrict the executive's power to remove that officer, whether or not that officer is inferior. ${ }^{56}$ While the Supreme Court has not yet ruled on this question, there seems little doubt that it would find prosecution to be such a core function. ${ }^{57}$ Prosecution lies at the heart of the executive's

53. See Myers v. United States, 272 U.S. 52, 161 (1926) (power to remove officials is "incidental to" the power to appoint).

54. See Humphrey's Ex'r v. United States, 295 U.S. 602, 624 (1935) (upholding restriction on President's power to remove Federal Trade Commissioner).

55. The two exceptions are: (1) pursuant to 28 U.S.C.A. § 546(d) (West Supp. May 1987), district court judges may appoint an interim United States Attorney to fill a temporary opening, if the President has within 120 days failed to affirm the Attorney General's interim appointment; see also United States v. Solomon, 216 F. Supp. 835, 842-43 (S.D.N.Y. 1963) (construing old version of $\S$ 546); and (2) judges may appoint disinterested special prosecutors to pursue criminal contempt proceedings in cases where the United States Attorney declines to do so, since "these [contempt] proceedings are not intended to punish conduct proscribed as harmful by the general criminal laws. Rather, they are designed to serve the limited purpose of vindicating the authority of the court." Young v. United States ex rel. Vuitton et Fils, 107 S. Ct. 2124, 2133 (1987).

A third possible exception, the judicially appointed independent counsel of the Ethics in Government Act of 1978, 28 U.S.C. $\S \S 49,591-98$ (1982 \& Supp. III 1985), is discussed infra note 57.

56. For a case prohibiting Congress from delegating appointment of core executive officials to another branch, see Buckley v. Valeo, 424 U.S. 1, 138 (1976) (statute allowing Congress to appoint members of Federal Election Commission, who have primary responsibility for bringing enforcement actions against violators of election laws, is unconstitutional). For the cases prohibiting Congress from restricting the executive's power to remove core executive officials, see Bowsher v. Synar, $106 \mathrm{~S}$. Ct. 3181, 3192 (1986) (Gramm-Rudman-Hollings Act unconstitutional insofar as Comptroller General is removable not by the President but only by Congress); Myers v. United States, 272 U.S. 52 (1926) (provision providing that postmasters cannot be removed by President without Senate's consent is unconstitutional); cf. Humphrey's Ex'r v. United States, 295 U.S. 602, 624 (1935) (upholding restriction on President's power to remove Federal Trade Commissioner, whose function was "predominantly quasi-judicial and quasi-legislative" rather than executive). Whether the postmaster in Myers or the Comptroller General in Bowsher really was more of a core executive official than the Trade Commissioner in Humphrey's Executor is, as a factual matter, perhaps open to question. What seems settled, as a matter of constitutional principle, however, is that Congress may neither restrict the President's power to remove, nor transfer to another branch the power to appoint, indisputably core executive officials.

57. In all likelihood, the Court soon will address this issue. The question of the constitutionality of judicial appointment and supervision of prosecutorial officers and restrictions on the executive's power to remove such officers has been at the center of the controversy over the independent counsel provisions of the Ethics in Government Act of 1978, 28 U.S.C. $\$ \S 49,591-98$ (1982 \& Supp. III 1985). The Act provides that a special three-judge court shall appoint independent counsel to investigate and prosecute high level officials in the Executive Branch. In In re Sealed Case, No. 87-5261, slip op. at 23 (D.C. Cir. Jan. 22, 1988), prob. juris. noted sub nom. Morrison v. Olson, 56 U.S.L.W. 3557 (U.S. Feb. 22, 1988) (No. 87-1279), the D.C. Circuit held, as its principal holding, that the independent counsel is not an inferior officer and therefore not appointable by a court. If it agrees that the Ethics Act is unconstitutional, the Supreme Court could follow this holding or it could go even further, as is suggested by the balance of the D.C. Circuit opinion, and find the independent counsel to be a core executive official and therefore not appointable even if an inferior officer.

Yet the Ethics Act provisions pose a particularly difficult constitutional puzzle; the Court could well uphold the Act as an exception to its traditional core powers jurisprudence. While judicial appointment and supervision of the independent counsel obviously threaten separation of powers, in this special case they also tend to reinforce the separation of powers by providing a means for dealing with unlawful conduct by members of the Executive Branch who, if prosecution were left to their superiors, otherwise might never be prosecuted. See id. at 22-23 (Ginsburg, J., dissenting) ("It is . . . unreasonable to expect an individual to investigate or prosecute his superiors. . . The Act thus 
role in our constitutional scheme, ${ }^{\mathrm{b8}}$ and it would be improper for any other branch to perform this function. ${ }^{88}$

Perhaps even more damaging to the constitutional scheme than diminishing executive power is the prospect of augmenting judicial power by giving courts the very powers taken from the executive. ${ }^{80}$ Courts may not exercise power that is "incongruous" with their constitutionally prescribed role, ${ }^{61}$ and few powers are more incongruous with the judicial power than the prosecutorial. ${ }^{62}$ Private challenge statutes that allow courts to order a prosecutor to proceed or to appoint a special prosecutor to take his place both diminish core executive power and augment judicial power. They should, therefore, be rejected as constitutionally unsound. ${ }^{63}$

operates as a means of maintaining the executive's proper-and properly circumscribed-constitutional role." (footnote omitted)). However the Court decides, it is unlikely to tamper with the main of its long-standing core functions jurisprudence.

58. See 1 Annals of Cong. 481 (J. Gales ed. 1789) (statement of James Madison) ("I conceive that if any power whatsoever is in its nature executive, it is the power of appointing, overseeing and controlling those who execute the law.").

59. Even Justice White, the Court's most prominent pragmatist on separation of powers, is likely to agree with this characterization. In re Sealed Case, No. 87-5261, slip op. at 50-51 (D.C. Cir. Jan. 22, 1988), prob. juris. noted sub nom. Morrison v. Olson, 56 U.S.L.W. 3557 (U.S. Feb. 22, 1988) (No. 87-1279), summarizes Justice White's position:

Although he has frequently dissented from cases overturning laws on separation of powers grounds and has advocated a pragmatic view of separation of powers doctrine, Justice White has repeatedly stressed the core executive nature of the prosecutorial function and the consequent importance of ensuring that the President retain the power to remove core executive officers at will. See, e.g., Bowsher, 106 S. Ct. at 3207 (White, J., dissenting) ("[T]here are undoubtedly executive functions that, regardless of the enactments of Congress, must be performed by officers subject to removal at will by the President."); INS v. Chadha, 462 U.S. 919, 1002 (1983) (White, J., dissenting) ("A legislative check on an inherently executive function, for example, that of initiating prosecutions, poses an entirely different question."); Buckley, 424 U.S. at 285 (White, J., concurring in part and dissenting in part) ("I would be much more concerned if Congress purported to usurp the functions of law enforcement . ...").

60. See The Federalist No. 47, at 303 (J. Madison) (C. Rossiter ed. 1961) ("Were [the power of judging] joined to the executive power, the judge might behave with all the violence of an oppressor." (quoting Montesquieu)); see also In re Padget, 678 P.2d 870, 873 (Wyo. 1984):

The statute here in question, [WYo. STAT.] $\$ 7-6-110 \ldots$ gives the district court the power to make the charging decision for the prosecuting attorney-indeed to order the prosecuting attorney to prosecute when he has reached the opposite conclusion. ... We think it is clear that as the charging decision is properly within the scope of duty of the executive branch, it is a violation of ... the Wyoming Constitution for this decision to be made by the judicial branch. Once the decision to prosecute has been made, then the judiciary becomes involved, but not before.

61. See Ex parte Siebold, 100 U.S. 371, 398 (1880) (courts may appoint executive officers only if such appointment is not "incongruous" with their judicial duties); see also Buckley v. Valeo, 424 U.S. 1, 123 (1976) (Congress may not assign executive or administrative duties of a nonjudicial nature to judges holding office under article III); Muskrat v. United States, 219 U.S. 346, 355 (1911) (article III courts must "carefully abstain from exercising any power that is not strictly judicial in its character, and which is not clearly confided to [them] by the Constitution." (quoting Gordon v. United States, 117 U.S. 697, 706 (1864))).

62. See Nader v. Bork, 366 F. Supp. 104, 109 (D.D.C. 1973) (Gesell, J.) ("The suggestion that the Judiciary be given responsibility for the appointment and supervision of a new Watergate Special Prosecutor . . . is most unfortunate. . . . The Courts must remain neutral. Their duties are not prosecutorial.").

63. Moreover, in the process of the criminal law, perhaps more than in any other area of law, a strict separation of powers is justified by the protections it provides for defendants' rights. For the judiciary to supervise a prosecution and to preside over that prosecution not only violates separation of powers but also may violate due process. Despite the official doctrine of Dreyer v. Illinois, 187 U.S. 


\section{A Proposal: Declaratory Judgment of Prosecutorial ABuse OF DISCRETION}

If due process concerns (primarily) prohibit privately controlled prosecution, and if the doctrine of separation of powers (primarily) prohibits judicially ordered or controlled prosecution, relief for victims seeking criminal prosecution is very limited. However, even though the executive does have constitutionally exclusive authority to prosecute, its discretion not to use that authority is reviewable. A legislature may establish a procedure by which individuals may challenge executive inaction and obtain a declaratory judgment if a court finds abuse of prosecutorial discretion.

\section{A. Judicial Review of Prosecutorial Inaction}

The Fifth Circuit's opinion in United States v. Cox ${ }^{64}$ suggests that there are severe constitutional restraints on judicial involvement in the prosecution function:

[I]t is as an officer of the executive department that [the United States Attorney] exercises a discretion as to whether or not there shall be a prosecution in a particular case. It follows, as an incident of the constitutional separation of powers, that the courts are not to interfere with the free exercise of the discretionary powers of the attorneys of the United States in their control over criminal prosecutions. ${ }^{65}$

Stretched to its interpretive limits, this dictum may be read to say that any judicial review of prosecutorial inaction would be constitutionally impermissible. ${ }^{66}$ This extension of the Cox dictum would be flawed, however. ${ }^{67}$

71,84 (1902) (federal courts may not subject a state's separation of powers schemes to due process scrutiny), the Supreme Court often has invalidated state governmental structures that endanger a defendant's due process right to an impartial judge. See generally Note, Justice Without Favor: Due Process and Separation of Executive and Judicial Powers in State Government, 94 YAle L.J. 1675 (1985) (arguing that Dreyer should be overruled). These concerns thus are of direct relevance to state courts, even apart from the analogy to federal separation of powers law used throughout this Note.

64. 342 F.2d 167 (5th Cir.) (en banc), cert. denied, 381 U.S. 935 (1965). The case involved the refusal of a United States Attorney to sign an indictment voted by a federal grand jury against several civil rights workers in Mississippi. The Fifth Circuit held that the United States Attorney's affixing or withholding of his signature was a matter of discretion and could not be coerced by the courts. Id. at 171.

65. Id. (footnote omitted); see also United States v. Nixon, 418 U.S. 683, 693 (1974) (dictum) ("Executive Branch has exclusive authority and absolute discretion to decide whether to prosecute a case" (citing Cox)).

66. Even though Cox concerned judicial control over a federal prosecutor, as a statement of separation of powers doctrine the case has had far-reaching influence in the state courts as well, being widely cited in cases concerning state constitutional separation of powers doctrines. See, e.g., State v. Carlson, 555 P.2d 269, 275 (Alaska 1976) (trial judge cannot accept guilty plea over opposition of prosecutor); State v. Cain, 381 So. 2d 1361, 1367 n.8 (Fla. 1980) (discretion of prosecutor is absolute); State v. Leonardis, 73 N.J. 360, 386, 375 A.2d 607, 620 (1977) (Conford, J., concurring) (decision of county prosecutor whether to prosecute is a function of executive, not judicial, branch).

67. In fact, Cox is a much more subtle and complicated case than many of the citations to it, and particularly to the dictum quoted above, would suggest. In addition to the majority opinion there are 
Examination of the constitutional locus of the executive's prosecutorial power reveals that a statutory grant of judicial review would be constitutionally permissible.

\section{The "Take Care" Clause and Judicial Review}

The constitutional basis for the power to prosecute is thought to inhere in the power granted by article II, section 3, clause 4, which provides that the President shall "take Care that the Laws be faithfully executed." 8 While the United States Constitution makes no explicit mention of the prosecution function, many state constitutions do make specific provision for the exercise of the prosecutorial power. ${ }^{69}$ Such state prosecutorial power also is governed in many cases by the standard of the take care clause, ${ }^{70}$ an analogue of which is present in virtually all of the various state constitutions. ${ }^{71}$

The take care clause exhibits two significant characteristics: First, it is a positive grant of power, a power to act, not a power not to act, a "duty, not a license."72 This fact is made particularly clear by the "faithfully" standard it carries. Second, the specific content of the executive's take care

three separate concurrences, each of which characterizes the issues of prosecutorial discretion and separation of powers differently. For example, while the majority holds that a judge could not order a prosecution to proceed against the wishes of the prosecutor, $342 \mathrm{~F} .2 \mathrm{~d}$ at 172, one concurrence suggests that a grand jury could so order, id. at 184 (Brown, J., concurring).

68. See United States v. Cowan, 524 F.2d 504, 512-13 (5th Cir. 1975); Nader v. Saxbe, 497 F.2d 676, 679 n.19 (D.C. Cir. 1974).

69. See, e.g., N.J. ConST. art. VII, § 2, para. 1; N.M. Const. art. VI, § 24.

70. Although the constitutions of some states specify more than three "branches" of government and locate the power to prosecute in a "branch" other than the one titled "executive," many of these states' courts have located prosecutorial authority in the take care clause. See, e.g., State ex rel. Unnamed Petitioners v. Connors, 136 Wis. 2d 118, 123-24, 401 N.W.2d 782, 784 (1987) (district attorney's authority derives from take care clause, even though Wisconsin constitution designates county district attorney "Administrative" rather than "Executive"); State v. Leonardis, 73 N.J. 360, 386, 375 A.2d 607, 620 (Conford, J, concurring) (county district attorney is functionally an executive branch official even though the New Jersey Constitution places local prosecutor under rubric "Public Officers and Employees"). But see Connors, 136 Wis. $2 d$ at 143, 401 N.W.2d at 792-93 (Abrahamson, J., concurring) (arguing that Wisconsin district attorney "functions at the juncture of the three branches of government . . . [having] quasi-executive, quasi-legislative and quasi-judicial powers"). Cf. Humphrey's Ex'r v. United States, 295 U.S. 602 (1935), discussed supra note 56.

Further, even though the constitutions of many states specify that the take care clause applies to the state's chief executive, see, e.g., Wyo. ConsT., art. IV, $\S 4$ ("The Governor . . . shall take care that the laws be faithfully executed"), these states' courts have applied this mandate to local prosecutors as well, see, e.g., In re Padget, 678 P.2d 870, 871 (Wyo. 1984) (arguing that "the executive function is to "take care that the laws be faithfully executed" "and, since "[t]he county and prosecuting attorney is a member of the executive branch of government," he takes his constitutional authority from the take care clause). This is the case despite the fact that prosecutors in most states are directly elected, see, e.g., Wyo. STAT. $\$ 9-1-802$ (1987) (district attorneys independently elected in each district), and that prosecutorial power does not always flow directly and fully from the governor's office, see A. GoLDStein, The Passive Judiciary: Prosecutorial Discretion and the Guilty Plea 69 (1981) (discussing implications of decentralization for judicial deference).

71. Forty-seven state constitutions have a take care clause or a functional equivalent. See, e.g., Fla. Const. art IV, $\S 1 ; \mathrm{KY}$. Const. $\S 69$.

72. See Sunstein, Reviewing Agency Inaction After Heckler v. Chaney, 52 U. CHI. L. REv. 653, 670 (1985) ("The "take Care' clause is a duty, not a license; it imposes an obligation on the President to enforce duly enacted laws."). 
power is supplied by a body of statutes. This is so even in the case of "core" functions like prosecution. ${ }^{73}$ These statutes are enacted by the legislature as holder of the power to "make all Laws which shall be necessary and proper for carrying into Execution ... [all] Powers vested," inter alia, in the executive. ${ }^{\mathbf{7}}$

The juxtaposition of these two central constitutional clauses suggests the legislature's large role in shaping what the executive can and cannot do. Thus, while the grand structure of the Constitution requires that the legislature give the prosecutorial power exclusively to the executive, ${ }^{75}$ the necessary and proper clause allows the legislature to determine the actual shape of that power. ${ }^{76}$

But does this "shaping" function include the power to limit the executive's power not to act? In Heckler v. Chaney, ${ }^{77}$ the Supreme Court said expressly that judicial review may be prescribed:

The general exception to reviewability . . remains a narrow one, but within that exception are included agency refusals to institute investigative or enforcement proceedings, unless Congress has indicated otherwise. In so holding, we essentially leave to Congress, and not to the courts, the decision as to whether an agency's refusal to institute proceedings should be judicially reviewable. ${ }^{78}$

Thus, at least in the administrative law context, ${ }^{79}$ courts frequently have reviewed inaction of enforcement agencies and found abuses of discretion. ${ }^{80}$ Since the take care clause is the basis of authority for executive

73. For a discussion of prosecution as a core function, see supra notes 55-59 and accompanying text.

74. See U.S. ConST., art. I, $\S 8$, cl. 18. Many state constitutions have analogous "necessary and proper" clauses. See, e.g., IDAho ConST. art. XXI, § 15; N.J. ConST. art. XI, § 2.

75. See In re Sealed Case, No. 87-5261, slip op. at 28 (D.C. Cir. Jan. 22, 1988), prob. juris. noted sub nom. Morrison v. Olson 56 U.S.L.W. 3557 (U.S. Feb. 22, 1988) (No. 87-1279) ("The constitutional scheme is as simple as it is complete-Congress passes the criminal law in the first instance, the President enforces the law, and individual cases are tried before a neutral judiciary involved in neither the creation nor the execution of that law.").

76. Cf. Lockwood v. Jordan, 72 Ariz. 77, 82-83, 231 P.2d 428, 432 (1951) (with the exception of assigning certain core executive branch functions to one of the other two branches, "the legislature's power to add or take away from these duties from time to time is full and complete"); Van Alstyne, The Role of Congress in Determining Incidental Powers of the President and of the Federal Courts: A Comment on the Horizontal Effect of the Sweeping Clause, LAw \& ConTEMP. ProBs., Spring 1976, at 102, 107 (necessary and proper clause "assigns to Congress alone the responsibility to say by law what additional authority, if any, the executive and the courts are to have beyond that core of powers that are indispensable, rather than merely appropriate, or helpful, to the performance of their express duties").

77. 470 U.S. 821 (1985).

78. Id. at 838 (citation omitted) (emphasis added). In Chaney itself, the Court read the judicial review provisions of the Administrative Procedure Act, 5 U.S.C. $\$ 704-06$ (1982), as containing a presumption against reviewability of agency inaction.

79. A number of commentators considering judicial review of prosecutorial inaction have suggested the analogy to administrative inaction. See K. DAvis, supra note 12; A. GoldsteIN, supra note 70, at 52-75; Note, The Special Prosecutor in the Federal System: A Proposal, 11 AM. CRIM. L. REv. 577, 586-607; Note, Failure to Prosecute, supra note 25.

80. See Chaney, 470 U.S. at 850 n.7 (Marshall, J., concurring) (citing twenty-five lower court decisions). 
enforcement in both the administrative law and criminal law areas, ${ }^{81}$ prosecutorial inaction also could be subject to review, should the legislature so provide. ${ }^{82}$

\section{Prosecution as a Reviewable Executive Function}

While administrative enforcement authority and prosecutorial power both are based on the take care clause, that fact alone does not establish the legislature's right to provide for review of prosecutorial inaction as it may for review of administrative inaction. ${ }^{83}$ The crucial question is whether there is any constitutional basis upon which reviewability of the two powers can be distinguished.

The only discernable difference seems to be that in the criminal law the executive also has the pardon power ${ }^{84}$ a power in some ways analogous to a "power" not to prosecute. ${ }^{85}$ Since Congress is forbidden from legislating review of pardons, ${ }^{86}$ it thus might be thought that nonprosecution also is unreviewable.

Undoubtedly, the prosecutorial power and the pardon power complement each other, ${ }^{87}$ further indicating that prosecution is a core executive function. Yet the pardon power is very different from any "nonprosecution power." The pardon power is a positive grant of constitutional authority; its uses are infrequent and narrow. ${ }^{88} \mathrm{~A}$ pardon binds current and

81. Id. at 832 .

82. See Nader v. Saxbe, 497 F.2d 676, 679 n.19 (D.C. Cir. 1974) (Wright, J.) ("The Executive's constitutional duty to 'take Care that the Laws be faithfully executed,' Art. II, $\S 3$, applies to all laws. ... It would seem to follow that the exercise of prosecutorial discretion, like the exercise of Executive discretion generally, is subject to statutory and constitutional limits enforceable through judicial review." (citations omitted)).

83. One objection may be that there are greater practical problems with review of the former than of the latter. See, e.g., Wayte v. United States, 470 U.S. 598, 607 ("[T] particularly ill-suited to judicial review. Such factors as the strength of the case, the prosecution's general deterrence value, the Government's enforcement priorities, and the case's relationship to the Government's enforcement plan are not readily susceptible to the kind of analysis that courts are competent to undertake."). But see A. Goldstein, supra note 70, at 55 (prosecutorial context is "familiar" one involving questions "integral to the judge's function").

84. U.S. ConsT. art. II, $\$ 2$, cl. 1 (President has the power "to grant Reprieves and Pardons for Offenses against the United States, except in Cases of Impeachment"). Nearly all the state constitutions grant to the governor (often together with a board of review) the power to pardon. See, e.g., Mich. Const. art. V, §14; R.I. Const. art VII, §4; UTAH Const. art. VII, \$12.

85. This analogy has led one commentator to suggest that the prosecutorial power itself derives from the pardon power. See Note, In Defense of Administrative Agency Autonomy, 96 YaLE L.J. 787, 800,812 n.160 (1987) (take care clause is "at most a modest grant of power"; presidential power rests primarily on other clauses of article II).

86. See Schick v. Reed, 419 U.S. 256, 266 (1974) ("A fair reading of the history of the English pardoning power, from which our Art. II, $\S 2$, cl. 1, derives, of the language of that clause itself, and of the unbroken practice since $\mathbf{1 7 9 0}$ compels the conclusion that the power flows from the Constitution alone, not from any legislative enactments, and that it cannot be modified, abridged, or diminished by the Congress.").

87. See United States v. Wilson, 32 U.S. (7 Pet.) 150, 160 (1833) (Marshall, G.J.) ("A pardon is an act of grace, proceeding from the power entrusted with the execution of the laws . ...").

88. See Schick, 419 U.S. at 266 ("The plain purpose of the broad power conferred by $\$ 2$, cl. 1 , was to allow plenary authority in the President to 'forgive' the convicted person in part or entirely[l] 
future administrations. ${ }^{89}$ With the exception of impeachable offenses, the executive may pardon any offense, at any time. ${ }^{90}$ Most important, for a pardon to have any effect, it requires an affirmative public act. ${ }^{\text {11 }}$

By contrast, there is no positive grant of nonprosecution power in the Constitution; this "power" is simply the nonuse of the take care clause prosecutorial power. Nonprosecution requires no affirmative act and may be reversed at any time. The power not to prosecute is in no way inherent in the power to prosecute; no matter how unwise a policy it might be, one can imagine a legislature eliminating discretion by calling for full enforcement. ${ }^{22}$ Despite its great importance to the functioning of the criminal law, ${ }^{93}$ prosecutorial discretion is simply a judicial construction, timehonored by legislative acquiescence. ${ }^{94}$

The "nonprosecution power" is accepted in part because the executive always has the option to use the pardon power to put the possibility of prosecuting a particular individual beyond question. But the very affirmative, irreversible, and public nature of a pardon may make it the focus of public scrutiny. ${ }^{95}$ It is much safer for the executive simply not to prose-

[or] to reduce a penalty in terms of a specified number of years ...."); see also ThE FEDERALIST No. 74, at 449 (A. Hamilton) (C. Rossiter ed. 1961) ("the principal argument for reposing the power of pardoning . . . in the Chief Magistrate is this: in seasons of insurrection or rebellion, there are often critical moments, when a well-timed offer of pardon to the insurgents or rebels may restore the tranquility of the commonwealth ...."); W. Humbert, The Pardoning PoWER of the President 82-133 (1941) (describing specific uses of pardon).

89. There is some suggestion that, even if a presidential pardon has been obtained through fraud, it may not be withdrawn. See W. Humbert, supra note 88, at 67-68 (citing W. TAFT, OuR CHIEF Magistrate and His Powers 123-24 (1916)).

90. But note that twenty-nine states allow use of the pardon only after conviction. See, e.g., state pardon provisions listed supra note 84 .

91. Supreme Court jurisprudence on the pardon power presupposes that a pardon must affirmatively be made in order to be effective. For two cases considering the conditions necessary for a pardon to be effective, see Biddle v. Perovich, 274 U.S. 480, 486-87 (1927) (commutation need not be accepted); Burdick v. United States, 236 U.S. 79 (1915) (full pardon must be accepted); see also 28 C.F.R. $\$ 1.7$ (1987) (suggested procedure for notification of grant of presidential clemency).

92. Cf. Note, supra note 32, at 1305 ("The decisions invoking the doctrine of prosecutorial discretion ... are predicated upon the assumption that the legislature granted discretionary power to federal prosecutors. . . . [W]here Congress has specifically directed executive conduct, a court violates no principle by ordering compliance with the statute.").

The Supreme Court itself, in The Confiscation Cases, 74 U.S. (7 Wall.) 454 (1868), may have recognized that the basis of the prosecutor's discretion not to prosecute lies in, and may be taken away by, legislative hands:

Public prosecutions, until they come before the court to which they are returnable, are within the exclusive direction of the district attorney, and even after they are entered in court, they are so far under his control that he may enter a nolle prosegui at any time before the jury is empanelled for the trial of the case, except in cases where it is otherwise provided in some act of Congress.

Id. at 457 (emphasis added).

93. See supra note 11.

94. See supra notes 7 and 8 and accompanying text.

95. While, in most cases, "[t] $\mathrm{the}$ administration of the pardoning power . . . is of such a character as not to attract wide attention," W. HuMBERT, supra note 88, at 5, in some circumstances use of the pardon has evoked significant political consequences, see, e.g., J. WITCOVER, MARATHON: THE PURSuIt of THE PRESIDENCY, 1972-1976 (1977) ("II]n the post-mortem[] [of the 1976 presidential race], many argued that in this very close election 'the Nixon issue'-meaning his pardon by Ford-though not extensively discussed in the campaign had been a prime factor [in Ford's defeat.]"). 
cute, particularly if it has any doubt about its decision to forgo criminal sanctions. By not exercising the pardon power, the executive leaves itself open to review.

\section{B. Constitutionally Permissible Judicial Action: The Declaratory Judgment}

With statutory authorization, courts may review prosecutors' decisions not to prosecute. ${ }^{86}$ However, they may go no further: Even upon a finding of abuse of discretion, the separation of powers doctrine prevents courts from ordering prosecution or taking over the prosecutorial function. ${ }^{\mathbf{9 7}}$ To answer the claims of victims who wish to challenge prosecutorial inaction, courts should be authorized to issue declaratory judgments that prosecutors have abused their discretion.

A declaratory judgment is used to "declare rights, status, and other legal relations, whether or not further relief is or could be claimed." Since it declares legal rights arising out of a real case or controversy, a declaratory judgment is not an advisory opinion. ${ }^{99}$

Having issued a declaratory judgment that a prosecutor has abused his discretion in declining to prosecute, ${ }^{100}$ a court would have good reason to "assume" that the prosecutor subsequently might change his mind and satisfy his obligations under the take care clause. ${ }^{101}$ While a court would

96. While judicial review of prosecutorial inaction without statutory authorization might be constitutional, cases such as Heckler v. Chaney, 470 U.S. 821 (1985), discussed supra notes 77-78 and accompanying text, together with the long history of broad prosecutorial discretion accorded the executive, seem to require clear authorization by legislative enactment.

97. In the administrative law context, this situation-judicial power to review without power to order-is fairly common. In Dunlop v. Bachowski, 421 U.S. 560 (1975), for example, the Supreme Court suggested:

The district court [on remand] may ... ultimately come to the conclusion that the [Secretary of

Labor's] statement of reasons [for not enforcing certain provisions of the Labor-Management

Reporting and Disclosure Act] on its face renders necessary the conclusion that his decision not

to sue is so irrational as to constitute the decision arbitrary and capricious.

Id. at 575. However, the Court viewed with great hesitation the possibility that the district court might have to "order the Secretary to bring a civil suit against the union to set aside the election." Id.

98. Uniform DeClaratory Judgments ACr $\$ 1$; see also Federal Declaratory Judgment Act, 28 U.S.C. $\$ \S 2201-02$ (1982 \& Supp. II 1984); FED. R. GIv. P. 57; E. BorchaRd, Declaratory JudGMENTS 10 (1934) ("The adjudication, not the command, is the essence of judicial power; and in our civilized communities, it is the adjudication, and not the command, which evokes respect and official sanction, because it is a determination by the societal agent appointed to perform that function, and thus irrevocably fixes legal relations."). An action for declaratory judgment need not be accompanied by, nor judged by the same standard as, a plea for injunctive relief. See Note, Need for Injunctive Relief as Prerequisite for Granting Declaratory Judgment, 56 YALE L.J. 139 (1946) (authored by Prof. Edwin Borchard).

99. See Aetna Life Ins. Co. v. Haworth, 300 U.S. 227, 241 (1937) (Dispute adjudicated under Declaratory Judgment Act of 1934 did set forth a "controversy" within the meaning of article III: "Where there is such a concrete case admitting of the legal rights of parties in an adversary proceeding upon the facts alleged, the judicial function may be appropriately exercised although the adjudication of the rights of the litigants may not require the award of process or the payment of damages.").

100. For a discussion of the basis upon which courts would make such a finding, see infra note 109.

101. Cf. Dunlop v. Bachowski, 421 U.S. 560, 576 (1975) ("We prefer therefore at this time to assume that the Secretary would proceed appropriately without the coercion of a court order when 
have no formal contempt power to order the prosecutor to prosecute, a plaintiff armed with a declaratory judgment would possess a kind of political power otherwise unavailable to him as private citizen and victim. ${ }^{102}$ Even were the prosecutor to remain steadfast in his refusal to prosecute, the declaratory judgment still would have served an important "signalling" function. ${ }^{103}$

\section{Mechanics of the Proposed Statute}

Under the proposed statute, a person ${ }^{104}$ could challenge the decision of a prosecutor not to prosecute a criminal prosecution. To have standing to make such a challenge, the person would have to demonstrate that he was directly affected by the decision not to prosecute. ${ }^{105}$ As in the civil law, the standing requirement would ensure adjudication of a genuine case or controversy. ${ }^{106}$ In addition, the standing requirement would prevent harassment and vindictive actions by persons who have not been directly affected by alleged criminal action.

finally advised by the courts that his decision was in law arbitrary and capricious."); Roe v. Wade, 410 U.S. 113, 166 (1973) ("We find it unnecessary to decide whether the District Court erred in withholding injunctive relief, for we assume that Texas prosecutorial authorities will give full credence to this decision that the present criminal abortion statutes of that state are unconstitutional.").

102. For a discussion of the inadequacy of other political remedies, see supra note 23.

103. Cf. Amar, Of Sovereignty and Federalism, 96 YALE L.J. 1425, 1503 (1987):

[T]he structure of horizontal separation of powers creates . . . incentives for signalling and political organizing. Even (or perhaps especially) if his veto is overridden, a president's veto message can serve as an important warning to the People that national legislators are attempting to breach the constitutional walls on their powers. So too with a judicial opinion, even (or perhaps especially) one that the political branches refuse to enforce.

104. "Person" might refer to defrauded corporations as well as individuals who are the victims of crime. Cf. Grosjean v. American Press Co., 297 U.S. 233, 244 (1936) (corporation is "person" within meaning of Fourteenth Amendment). In "tailoring" its private initiation statute, see infra note 111, a legislature could decide which reading it preferred.

105. Standing would be available to those who actually were victims of crimes and, in the case of homicide, to surviving family members. $C f$. Dohaish v. Tooley, 670 F.2d 934 (10th Cir. 1982) (father of murder victim seeking to compel prosecution of son's alleged murderer); Comment, supra note 23, at 232 (offering private prosecution scheme that would allow private prosecution of victimless crimes, such as gambling and illegal liquor sales, "upon a showing that the crime threatens public confidence in law and order, or undermines the integrity of governmental institutions").

106. A complainant would have to show, for example, that he was within the "zone of interests" and that he had suffered an "injury in fact." See Association of Data Processing Serv. Orgs. v. Camp, 397 U.S. 150, 152 (1970). The standing requirement would bar complainants whose interest in seeing a particular criminal statute enforced is, for example, primarily political, as opposed to personal.

In this regard, compare Linda R.S. v. Richard D., 410 U.S. 614 (1973) (no standing for plaintiff seeking to compel prosecution), discussed supra notes 2 and 3, with NAACP v. Levi, 418 F. Supp. 1109 (D.D.C. 1976) (civil rights organization and widow alleged that failure to investigate death of black man in state police custody was abuse of discretion by federal law enforcement officers; judicial relief "in the nature of mandamus" deemed "appropriate"). The Levi court, in its effort to grant relief to plaintiffs in the wake of outrageous prosecutorial misconduct, avoided the categorical language in Linda R.S. that would bar such action. Instead, the Levi court read Linda R.S. as a more conventional standing case and found that, while the plaintiff in Linda R.S. had "failed to allege a sufficient nexus between her injury and the government action which she attacks," id. at 1115 (quoting Linda R.S., 410 U.S. at 617), the Levi plaintiffs had shown such a nexus and therefore merited standing. 418 F. Supp. at 1115; see also Inmates of Attica Correctional Facility v. Rockefeller, 477 F.2d 375 (2d Cir. 1973), discussed supra note 21. 
Filing of the complaint would be followed by an in camera hearing ${ }^{107}$ attended by a judge, the complainant, and the prosecutor who refused to bring the prosecution. On the motion of the prosecutor, a portion of the hearing also could be held ex parte. ${ }^{108}$ The purpose of the hearing would be to consider only the question of whether the prosecutor had abused his discretion in refusing to bring a prosecution. ${ }^{109}$ Review never would be de novo. ${ }^{110}$

This deferential standard would minimize the possibility that judicial review might undermine the primacy of the prosecutor's office; the executive would retain broad discretion in allocating resources and in setting enforcement priorities. In addition, the deferential standard of review and the standing requirement would help prevent any significant increases in caseload. ${ }^{111}$ If the court were to find that the prosecutor had abused his discretion, the court would issue a declaratory judgment to that effect.

107. The secrecy of the proceedings would serve two functions. First, it would protect the reputation of an accused until such time as a prosecution actually was commenced. Second, it would allow a prosecutor to present sensitive evidence to a judge, for example, that he chose not to pursue a particular prosecution because the investigation into an alleged criminal act fit into a larger, possibly undercover, investigative scheme that required the prosecutor's office to refrain from prosecuting at a particular time. But of. State ex rel. Newspapers, Inc. v. Circuit Court, 124 Wis. 2d 499, 505-09, 370 N.W.2d 209, 213-15 (1985) (proceedings before judge to determine whether private criminal complaint should be filed after district attorney refused to issue complaint are presumptively open to public and may be closed only upon a showing of compelling reason).

108. This procedure would allow for cases where the evidence was of such a secretive nature that revealing it to a complainant would be objectionable to the prosecutor.

109. Reasons that the prosecutor might offer in defending his decision not to prosecute are suggested by the considerations a federal prosecutor is required to weigh in determining whether to prosecute: (a) federal law enforcement priorities; (b) the nature and seriousness of the offense; (c) the deterrent effect of prosecution; (d) the accused's culpability in connection with the offense; (e) the accused's history of criminal activity; ( $f$ ) the accused's willingness to cooperate in the investigation or prosecution of others; and (g) probable sentence or other consequences if the accused is convicted. See U.S. Dep't of Justice, Principles of Federal Prosecution 7 (1980). A prosecutor would be deemed to have abused his discretion if his decision not to prosecute either failed to take into account factors similar to these, or if it considered improper factors, including the defendant's race, sex, religion, national origin, or political association, the prosecutor's feelings concerning the defendant or the victim, or the possible effect of the decision on the prosecutor's professional or personal circumstances. See id. at 14 .

110. Cf. State ex rel. Unnamed Petitioners v. Connors, 136 Wis. 2d 118, 401 N.W.2d 782 (1987), (state's private criminal complaint statute, Wis. STAT. ANN. \$ 968.02(3) (West 1985), violated the state's constitutional doctrine of separation of powers by not only providing for judicial review of a prosecutor's inaction-a procedure which, the court implied, see id. at 134-35, 401 N.W.2d at 789, by itself might be constitutional-but also permitting a de novo judicial examination of the merits of the case).

111. It is difficult to predict how many cases and what additional costs would result from passage of the proposed statute. As mentioned supra note 4, previous private challenge statutes have made a negligible contribution to court dockets. Nonetheless, it is possible that a well-publicized and wellformulated statute would increase a court's caseload significantly. Moreover, the costs of added hearings and other proceedings could impose an additional budgetary strain on prosecutors' offices. In anticipation of such costs, a legislature could tailor the statute to limit the availability of judicial review to serious felony cases or to repeat offender crimes of the sort mentioned supra note 22 . The extent to which the costs of this scheme might outweigh its benefits is a question of allocation of social resources that could be fully informed only by empirical study. 


\section{CONCLUSION}

The model statute offered in this Note provides legislatures with a mechanism for a constitutionally firm recognition of the interest of private individuals in the initiation of criminal proceedings. It guards against harassment and unfair treatment of defendants through its limited scope and procedural safeguards. In addition, it restricts a court's role to one of review, thereby maintaining prosecution as an exclusively executive function. Allowing private individuals to obtain a declaratory judgment that a prosecutor has abused his discretion will provide a signal that the prosecutor has been "unfaithful" in the execution of his duties. Ultimately, the scheme should promote broader public confidence in the criminal justice system. 
